\title{
THE LOSS AND REACQUISITION OF CAFFA: THE STATUS OF THE GENOESE ENTREPÔT WITHIN THE BORDERS OF THE GOLDEN HORDE
}

\author{
Roman Hautala ${ }^{1,2}$ \\ ${ }^{1}$ Marjani Institute of History of Tatarstan Academy of Sciences \\ Kazan, Russian Federation \\ ${ }^{2}$ University of Oulu \\ Oulu, Finland \\ romanhautala@gmail.com
}

\begin{abstract}
Research objectives: To analyze both the circumstances of the armed conflict of Genoese Caffa with the troops of the Golden Horde ruler, Toqta Khan, in 13071308, which ended with the temporary expulsion of Italian merchants from the Jöchid territory, and their return to Caffa under Toqta's nephew and successor, Özbeg Khan.

Research materials: The information on the conflict between the Genoese and Toqta Khan is contained in an anonymous continuation of the chronicle of the Genoese Archbishop, Jacopo da Varagine, dating to the middle of the fourteenth century; in the chronicles of the Mamluk authors, Baybars al-Mansuri and al-Nuwayri; and in a local Greek source, namely the Sugdeian Synaxarion. In turn, sources that provide information about the circumstances and conditions of the return of the Genoese are much more diverse. Of course, the most important details are contained in the official documents of Genoa and Caffa. Valuable details are also contained in the missionary sources of the Franciscans preaching the gospel within the Golden Horde. For its part, the Franciscan information is useful to compare with that found in Rus'ian sources regarding the relations of Catholic and Orthodox prelates with the Khan of the Golden Horde.

Research novelty: This study highlights that the use of Franciscan sources appears to be extremely useful to complement the analysis of the relationship of the Genoese entrepôt of Caffa with the local authorities.

Research results: An analysis of the conflict between the Genoese and the local authorities, along with the conditions of their return negotiated with the new Khan of the Golden Horde, reveals the obvious fact that Caffa, having undoubtedly grown in the Golden Horde period due to the activities of the Genoese immigrants, had to recognize its submission to the Jöchid rulers from its very foundation. The Genoese administration likewise recognized this dependence during the restoration of Caffa in the first years of Özbeg Khan's reign.
\end{abstract}

Keywords: history of the Golden Horde, Italian trade in the Mongol Empire, Genoese entrepôt of Caffa, Catholic missionary activity in the east, Latin and Muslim sources

For citation: Hautala R. The Loss and Reacquisition of Caffa: The Status of the Genoese Entrepôt within the Borders of the Golden Horde. Zolotoordynskoe obozrenie $=$ Golden Horde Review. 2021, vol. 9, no. 2, pp. 247-263. DOI: 10.22378/2313-6197.2021-9-2.247263 
According to the convincing arguments of Michel Balard, the first Genoese immigrants were able to settle in Caffa between 1270 and 1275, and by about 1285 Caffa grew to the scale of a large Genoese entrepôt, which was destined to play a leading role in the economic life of the Ligurian capital over the next two centuries [3, p. 114-118]. However, the question of the origin of the Genoese entrepôt and its initial status within the borders of the Golden Horde remains unclear due to the absence of any documents (or their traces) that would reflect the conditions for a possible agreement between the Genoese and Möngkä Temür Khan or at least a local government of Solkhat. We can only guess whether Caffa was bought by the Genoese or received as a gift in exchange for a guarantee of the payment of any taxes. The status of the Genoese who regularly visited Caffa or decided to settle in a new Genoese entrepôt, remains unclear, too. Obviously, the Genoese did not lose touch with the metropolis and continued to enjoy the privileges granted to them by the citizenship of the Ligurian capital. However, contemporary sources do not contain sufficient information regarding the degree of simultaneous and parallel subordination of the Genoese inhabitants of Caffa to the power of the Jöchid khans and leave the impression that the Caffa's comune asserted its independent status within the Golden Horde and recognized its dependence solely on the Ligurian metropolis.

The fact that this impression is misleading is confirmed by the analysis of the first armed conflict between the Genoese and the Jöchid authorities, which forced Western merchants to agree to new, less favorable conditions put forward by the Golden Horde Khan. As with the initial agreement, we do not have the text of a new agreement between Genoa and the Khan. Nevertheless, the circumstances of the return of the Genoese to Crimea and the restoration of Caffa are reflected in written sources in a larger volume and suggest the conditions of the new agreement with greater credibility. Revealing the details of the new treaty remains largely hypothetical. Nevertheless, the sources given below reflecting the consequences of this treaty, leave no doubt that the comune of Caffa recognized its subordinate status within the borders of the ulus of Jöchi and probably had recognized it from the very beginning of its existence.

\section{The Expulsion of the Genoese from the Golden Horde}

According to an anonymous continuation of the chronicle of the Genoese Archbishop, Jacopo da Varagine, of the middle of the fourteenth century, on 4 October 1307 Toqta "ordered to capture all the Genoese in his entire empire", and in November of that year he sent his son Il-Basar with troops to Crimea to besiege Caffa. The Genoese held the city's defenses with the local Greeks for eight months, but on 20 May 1308 they were forced to leave and burn the city:

"In the year of Lord 1307, on the feast of St Francis, Toqta, the Emperor of Tartars in the domain of Gazaria, because of the arrogance that the Genoese repeatedly expressed in his Empire, commanded to capture all the Genoese in his entire Empire and seize their property. And this was done so that the merchants who were in Sarai were arrested and robbed, but later, according to the instructions of the Emperor, some of them were taken to Solkhat, and several of them reached Caffa. The rest remained there imprisoned, and later almost all of them died of cold, sword and disease. In the same year, the aforementioned Toqta sent for the destruc- 
tion of Caffa his son Il-Basar ${ }^{1}$, who arrived in Gazaria the same year in the month of November and gathered there his army consisted of one hundred thousand horsemen and foot soldiers and came to Caffa. And there were 300 Genoese and 300 Greeks, who, relying on the help of God, courageously defended themselves and their households against the mentioned enemies of God. And after the mentioned Tartars brutally hit the mentioned city of Caffa with many battles and fires for almost eight months, finally the Genoese who were there saw that due to lack of strength they could not keep the city. They gathered a general council, on which it was decided to leave the city climbing aboard. So on 20 May 1308, Caffa was abandoned and completely burnt by the hands of the mentioned Genoese" .

Obviously, the anonymous Genoese author of the report of this conflict could not find an explanation for these repressions or did not want to reveal their true reason, claiming that Toqta's anger was caused by "the arrogance that the Genoese repeatedly expressed in his Empire"3. He did not explain, therefore, how Toqta Khan managed to endure the similar behavior of Italian merchants all the previous sixteen years of his reign. Al-Nuwayri, in turn, based on the account of Baybars alMansuri, but supplementing it with some details, dated the arrival of information on these events to Egypt back to 707 AH (3 July 1307 - 20 June 1308) and explained that the reason for the repressions was Toqta's desire to take revenge on the "Genoese Franks in Crimea, Caffa and in the Northern possessions for the (various) cases that he was informed about them, including for the capture of Tatars' children by them and their sale to Muslim countries" [46, p. 120 (Baybars alMansuri), 162 (al-Nuwayri)]. However, the latter explanation was hardly true, since Toqta had not previously objected to the trade of Qipchaq slaves, as neither his predecessors nor the successors did. Rather, it was an excuse that Toqta used to justify the repression [3, p. 151].

\footnotetext{
${ }^{1}$ According to al-Nuwayri, Il-Basar (Ir-Bysa[r]) "performed the functions of commander of the troops under his father", and according to several other Mamluk chroniclers, he died in $709 \mathrm{AH}$, that is, between 11 June 1309 and 30 May 1310 [46, p. 123 (Baybars al-Mansuri), 162 (al-Nuwayri), 384 (Ibn Khaldun), 513 (al-Ayni)]. Apparently, Vladimir Tizengauzen incorrectly read the date of his death $(707 \mathrm{AH})$ in the text of al-Nuwayri [9, p. 116, note 110].

2 "Anno Domini .MCCCVII., in festo beati Francisci, Toctai imperator Tartarorum in dominio Gazarie, propter multas superbias quas Ianuenses fecerant in suo imperio, precepit quod omnes Ianuenses essent capti per totum suum imperium in here et persona. quod et factum fuit, ita quod mercatores, qui erant in Saray, capti fuerunt et depredati; sed postea ex precepto dicti imperatoris persone eorum usque in Sulcati ducti fuerunt et aliqui in Caffa venerunt, reliqui remanserunt ibi incarcerati, qui postea quasi toti frigori, gladio et desasio perierunt. dicto autem millesimo dictus Thoctai missit ad destructionem Caffe Elbazar filium suum qui aplicuit in Gazaria dicto millesimo de mense novembris et ibi congregavit exercitum suum inter equites et pedites centum milia et venit in Caffa. erant Ianuenses .CCC. et Greci .CCC. et sperantes in adiutorio Dei ad se deffendendum et familias eorum et contra dictos inimicos Dei se viriliter posuerunt et cum multis preliis et incendiis dictam terram Caffa dicti Tartari fere per menses .VIII. duriter aflixissent. ultimo, videntes Ianuenses ibi existentes quod propter deficientiam quam non habebant terram tenere non potuebant, fecerunt conscilium generale in quo deliberatum fuit derelinquere terram et ascendere in lignis. ita quod die .XX. maij .MCCCVIII. derelicta fuit Caffa et tota igne combusta manibus dictorum Ianuensium" [27, p. 479-480]. According to the Sugdeian Synaxarion, Caffa was plundered by the Tatars the day after its capture, 21 May 1308 [31, no. 125, p. 129; 2, no. 120, p. 613].

${ }^{3}$ Nicola Di Cosmo showed confidence in this statement of the Genoese anonymous [10, p. 413].
} 
For his part, Bertold Spuler believed that the reason for the repressions, in addition to the slave trade, was the cooperation of the Genoese with the Ilkhanate. This explanation, however, was his dubious conjecture, since he did not provide references to sources that would confirm it [44, p. 84]. Equally speculative is the hypothesis of Viktor Myts, according to which Toqta, "having settled state affairs" by destroying Nogai and his supporters, decided to take revenge on the Genoese for their alleged alliance with Nogai, also weakly justified by Myts. Myts did not explain why Toqta, in this case, hatched plans for revenge on the Genoese for so long and implemented them only seven years after the death of Nogai. In the Myts's reference, al-Maqrizi does not really mean the stabilization of the internal situation in the Golden Horde by the term "settling affairs", but the reconciliation of the Mamluk sultan al-Malik al-Nasir with the Ilkhan Öljeitü [46, p. 436; 30, p. 75].

The Virgil Ciocîltan's hypothesis, recently introduced by Marie Favereau as well, seems more significant: Toqta could interrupt the slave trade and, accordingly, expel Italian merchants from his possessions in order to punish the Egyptian sultan for his unwillingness to conduct joint military operations against the Ilkhanate and deprive his army of replenishment with new Qipchaq slaves [7, p. $170-171 ; 12$, p. 343]. However, it is difficult to find direct confirmation of this hypothesis in the sources. Therefore, perhaps a more plausible reason will be presented below: Toqta could enact reprisals against Italian merchants in connection with their sharp refusal to accept the intention of the Khan to raise the main tax on their trading activities. In the end, Western merchants had to accept the new conditions. However, they did this already under the new Khan, who allowed the Genoese to return to Caffa on the conditions that they tried to initially reject.

\section{The Return of the Genoese to Caffa}

The Genoese, obviously, returned to Caffa at the first opportunity and, apparently, shortly after the departure of the Tatar troops. This is confirmed by one notarial act from the State Archives of Genoa: in February 1310, Galverio Bibia di Sant'Ambrogio contracted in Caffa his 17-year-old slave woman named Caterina of Magyar origin ("de proienie maiariorum") to Nicolosa, the widow of a notary Giovanni Rosso [45, p. 453]. In addition, the letter of the Dominican General Master, Bérenger de Landore, addressed to Franco of Perugia, the Vicar of the Caffa's Dominicans, implies the presence of the Friars Preachers there already in 1312 [28, p. 313,318$]^{4}$.

In turn, an anonymous continuator of the chronicle of Jacopo da Varagine indicates that, "thanks to the grace provided to them by Özbeg, the Emperor of Tartars", the official representatives of the comune of Genoa, namely, Antonio Grillo and Niccolo di Pagano, were able to rebuild Caffa by $1316^{5}$. This latter date, obviously, did not mean the moment of granting permission by Özbeg, but visible ef-

${ }^{4}$ The Italian Dominican Franco of Perugia led his fellow friars of the Order in the Golden Horde and Ilkhanate since about 1304 [24, p. 2; 23, p. 18], until Pope John XXII elevated him to the dignity of the first Latin Archbishop of Sultania in the Ilkhanate by the bull Redemptor noster of 1 April 1318 [17, p. 201].

5 “Anno Domini .MCCCXVI. redifficata fuit civitas Caffe per dominum Antonium Grillum et dominum Nicolaum de Pagana sindicos communis Ianue per gratiam sibi concessam per Usbech imperatorem Tartarorum" [27, p. 481]. 
fects of Caffa's original restoration orders ${ }^{6}$. Subsequently, the restoration of Caffa was subordinated to the leadership of a special office of the comune of Genoa, called the "Eight Wise Men [appointed by the comune of Genoa] over the affairs of navigation and the Black Sea" (Octo sapientes [constituti per comune Ianue] super factis navigandi et Maris Maioris), later called the "Office of Gazaria" (officium Gazarie) and established in 1313 by a council of 24 wise men of Genoa [see especially 43, col. 406-409]. This office took over all the functions of the former "trade managers" (tractatores mercantiae) established in Genoa in the middle of thirteenth century [33, p. 424, 439, note 3]. However, unlike the latter, it received complete independence in addressing the general and particular issues of navigation of the Genoese both in the Black and Mediterranean Seas, and beyond Gibraltar.

Nevertheless, initially this office was created to address extremely topical issues of the return of the Genoese to the Crimea and the joint efforts of the rulers of Solkhat, Sinop and Trebizond to prevent the Genoese from settling in Caffa again. One of the main reasons for creating the Office of Gazaria was the need to resolve the consequences of the recent attack on Caffa, in May 1313, by the combined fleet of the Trapezuntine Emperor, Alexios II, and Gazi Çelebi, the Turkish ruler of Sinop, as well as the synchronous attack of troops from Solkhat $[8$, p. 519, 528, 530. See also 27, p. 480-481; 41, p. 502; 20, p. 282; 3, p. 202]. The damage suffered by the Genoese of Caffa and other Crimean ports during this attack was estimated at 250,000 Komnenoi's aspers (asperi comninati) during negotiations in the town of Arzeron next to Trebizond next year, which culminated in the signing of the Genoese-Trapezuntine treaty on 26 October 1314. Under the same agreement, Alexios II undertook to compensate for the damage caused by local Greeks to the Genoese Giovanni Fantinanti and Giovanni di Chiavari during the attack on their ships in the port of Trebizond, probably in parallel with the Emperor's Crimean expedition [8, p. 514, 519-520, 528. See also 20, p. 282-284; 4, p. 283-284].

The acquiescence of the Trapezuntine Emperor was the result of specific measures taken in this regard by the Genoese Office of Gazaria. Immediately after taking office on 1 May 1314, the eight "wise men" of the Office set about equipping a flotilla consisting of five galleys led by the Admiral, Accellino Grillo, which, in addition to transporting the ambassadors of the Genoa to the Trapezuntine Emperor, was sent at the end of May or early June of that year east to "protect the Black Sea"7 . After arriving in Trebizond at the end of August 1314, the flotilla launched military operations in the uncertain waters of the Black Sea until the conclusion of the Genoese-Trapezuntine agreement, mentioned above, on 26 October of that year [1, p. 54-58].

By the time this agreement was signed, the Genoese had already settled firmly in Caffa, and in 1314 they were able to successfully repulse the next joint attack by the Gazi Çelebi's fleet and Solkhat's troops. This fact was eloquently described by the continuator of the Jacopo da Varagine's chronicle: "and the following year the mentioned Çelebi came to the mentioned place [of Caffa] and found there three little ships and one cocha of Giacomo di Carlo, and, having nine galleys and the

\footnotetext{
${ }^{6}$ See the mention of these original decrees in [43, col. 407].

7 "Ad custodiam maris Maioris" [1, p. 77 (act of the notary Francesco da Silvia, rogated in Samsun on 22 December 1314, with reference to the equipping of the flotilla). See also ibidem,
} no. $2-11$, p. $76-81]$. 
help of Solkhat, he could not capture anything as a result of military operations, but took great damage there and came back home with shame, sorrow and damage" $"$.

\section{The Yarliq of 1314}

In the end, Özbeg Khan's patronage was supposed to put an end to the attacks on Caffa. Özbeg provided this protection after concluding an agreement with representatives of the comune of Genoa, as reported by the continuator of the Jacopo da Varagine's chronicle in the fragment mentioned above. Nevertheless, it can be assumed with a certain degree of certainty that this agreement was concluded in 1314, since any attacks on Caffa ended after that year. The yarliq, apparently granted to the Franciscans of Caffa at the same time as the conclusion of this agreement, is an additional argument in favor of this year. The text of this yarliq is preserved only in the Latin translation, at the end of which the exact date of this document is indicated - 20 March 1314:

"By the power of the eternal God and with the approval of [his] great majesty, we, Özbeg, convey these our words: The Latin priests possessing this privilege, who call themselves the minor brothers according to their habit, so that they, namely, move with a serene soul, praying to God and blessing, the privilege granted by Culuk $^{9}$, our progenitor, as well as his successor, our elder brother ${ }^{10}$, the Emperor, we also now give in accordance with the same content, that is, the privilege that, praying to their God, the slaves of Christ, the mentioned Latin priests, go around, teaching Christian law to many. Let absolutely no messenger heading for the census of the army take [anyone] from them to the army under this pretext and take the means of transportation or anything else that would harm them. Let the officials of taxes and tributes not receive neither demand tributes nor census from them neither concern any of their property. Let no one inflict violence or oppression on them, fracturing their church ${ }^{11}$ or destroying their houses or places of residence; but by constructing a church or hanging bells, let them govern the people of Christian law and come out to us to report on the reasons for arriving from far or near and to make us a written report. How, in turn, will we favor them in graces, we shall know $^{12}$. This privilege [is given] in the year of the leopard, in the third month, on the fourth day of the month, near the saffron reed $^{13,, 14}$.

8 "Et anno sequenti venit dictus Zalabi in dicto loco et invenit ibi tria ligna parva et unam cocha Iacobi de Karlo et ipse habens galeas .VIIII. et adiucatorium Solcati preliando nil capere potuit. sed magnum dampnum ibi habuit et cum verecundia, tristitia et dampno ad propria est reversus" [27, p. 481. See also 20, p. 283].

9 The nickname of Özbeg's grandfather, Möngkä Temür Khan, also known from later sources of the fifteenth and sixteenth centuries [47, p. 205 ("Shajarat al-atrak"); 22, p. 40 (Khwand-Amir); 32, p. 39 (Ötemish Hajji)].

${ }^{10}$ More precisely, the uncle and predecessor of Özbeg, Toqta Khan [34, p. 60].

${ }^{11}$ The Church of St Agnes, according to the bull Ad universalis ecclesiae of Pope John XXII of 26 February 1322 [14, p. 143].

${ }^{12}$ Apparently, meaning by this phrase that the contents of this privilege will become known to all relevant officials. Cfr. with the Rus'ian translation of the Möngkä Temür Khan's yarliq in [6, p. 467].

${ }^{13}$ Obviously, Sary Kamysh, somewhere in the Lower Volga region.

14 "In virtute eterni dei et magne maiestatis suffragio, Nos Vsbek mandamus hec verba nostra: Istud priuilegium tenentes sacerdotes latini qui suo more se fratres minores appellant, $\mathrm{vt}$ videlicet animo tranquillo consistentes, deum rogando, benedictionem faciendo incedant, 
The privileges contained in this yarliq, with the exemption of Franciscans from paying all taxes and military service, are clear evidence of the practice of religious tolerance by the Muslim Özbeg Khan. His confessional tolerance is also confirmed by the permission to build the Franciscan cathedral church in Caffa and even the permission to ring the bells on it - this right remained valid even after the next year Özbeg Khan banned the ringing of Christian bells in other cities of his domain ${ }^{15}$. Khan's separate permission to "go around, teaching Christian law to many" implied freedom of movement along the Golden Horde and was of paramount importance to Western missionaries. So, in 1320, the Hungarian Franciscan Johanca specified in his letter to the Franciscan General Minister, Michele da Cesena, that he and other friars of his Order were able to reach the modern territory of Bashkiria about six years before writing this letter, that is, immediately after the Özbeg's yarliq was granted [29, p. 67].

The recognition of the Franciscans' right to "govern the people of Christian law" seems particularly interesting in this context. Obviously, this expression implied the subordination of the friars and secular members of their Order to the head of the Franciscans, although the leader of the Franciscans and the direct recipient of the yarliq was not named by name in this document. Theoretically, he could be the "Vicar of Gazaria", that is, the former head of the Franciscans in the Golden Horde, mentioned for the first time by the Franciscan Giovanni da Montecorvino in his letter of 13 February 1306 [48, p. 351-352]. However, this nameless vicar was supposed to leave the ulus of Jöchi two years later, along with all the Franciscans as well as Western merchants, during the repressions of Toqta, mentioned above; and his belated return to the Golden Horde is testified only by the bull Nuper ad nostri of Pope John XXII of 22 November 1321 [5, p. 212]. Therefore, it is much more likely that another Franciscan, well known from contemporary sources, was the actual recipient of the yarliq - Jerome of Catalonia, whom Pope Clement V elevated to the rank of Latin Bishop by the bull Rex regum of 19 February 1311 [5, p. 74] and who appeared in Caffa sometime after that, was the actual head of the Franciscans of the Golden Horde, starting from 1312 onwards. Subsequently, on 26 February 1322, Pope John XXII confirmed the fact that Jerome was previously appointed the Bishop "in the lands of Tartars" in his bull Ad universalis ecclesiae and approved Friar Jerome at the head of the Latin diocese of Caffa with canonical jurisdiction, which extended to the entire western and central territory of the ulus of Jöchi ${ }^{16}$. The Genoese documen-

priuilegium quod dederat Culuk progenitor noster et successor eius, frater noster senior, inperator, nos eciam nunc dedimus secundum eundem tenorem, priuilegium scilicet quod deum suum orando xristi servi, dicti sacerdotes latini, legem xristianam multis dicendo ambulent. Nullus omnino nuncius ad recendendum exercitum vadens, ab illis nomine exercitus abstrahat, nec voituram aut aliud eis dampnificum ab illis accipiat; vectigalium vel tributorum officiales nec tributum nec censum ab eis accipiant nec exigant, nec aliquid de rebus ipsorum contingant. Nemo eis violenciam inferat aut oppressionem, ecclesiam frangendo vel domos aut loca destruendo eorum; set faciendo ecclesiam aut campanas xristiane legis homines regant, de longe vel de prope veniencium causas nobis dicendo, nobisque recordacionem faciendo incedant; qualiter autem eis fauebimus in graciis, nos sciemus: hoc priuilegium anno pardy mense $3^{\circ}, 4^{\text {ta }}$ die mensis apud croceam arundinem" [29, p. 65].

${ }^{15}$ Pope John XXII reprimanded Özbeg for imposing this prohibition in his bull addressed to the Khan on 28 March 1318 [5, p. 148]. Ibn Battuta, for his part, witnessed the use of bells by Christians of Caffa in 1334 [16, p. 470-471].

16 "A villa de Varna in Bulgaria usque Saray" [14, p. 142-143]. 
tation, in turn, also confirms the fact that Friar Jerome headed the Caffa's Franciscans by 1316 and built the church of St Agnes in its citadel [43, col. 407], which was destined to become the center of the new Latin diocese ${ }^{17}$.

Thus, the 1314 yarliq was received by the Catholic prelate, who later headed the first Latin diocese on the territory of the Golden Horde taking advantage of the recognition of his legal autonomy by Özbeg Khan. Apparently, the year before, Özbeg granted similar privileges and recognition of legal autonomy to the Kyiv Metropolitan, Petr (with a residence in Vladimir), although the yarliq that the Khan endowed with the Orthodox Metropolitan in 1313, did not preserve in the original, but only in a forged Rus'ian translation made in the Metropolitan Chancellery of Moscow in the $1540 \mathrm{~s}^{18}$. The fact that this yarliq was falsified is confirmed not only by its extremely long content, noticeably different from all the known yarliqs of the Mongol Khans, but also by its erroneous dating: at the end of the translation, the yarliq erroneously dates back to the "year of the hare", which corresponded to 1315, and not 1313 of the Mongolian calendar. It is obvious that the authors of the fake not only had a poor understanding of the dates of the Mongolian calendar, but also did not have the text of the 1313 yarliq on their hands. Therefore, they literally borrowed the dating of the Möngkä Temür Khan's yarliq of 1267 or $1279^{19}$ and used the contents of this yarliq as a model for their significantly expanded falsification [6, p. 464].

Despite this falsification, the Metropolitan Petr really should have received a yarliq from Özbeg as a result of his visit to the Khan's headquarters, as a number of Rus'ian chronicles testify [36, p. 87-88; 40, p. 102; 39, p. 160;37, p. 97; 38, p. $107 ; 35$, p. 178]. The same chronicles clearly indicate the fact that the Kyiv Metropolitan arrived at Özbeg's headquarters, accompanied by the Great Vladimir Prince, Mikhail Iaroslavovich, who also went to the new Khan to assert his own power in northwestern and northeastern Rus'.

Of course, this analogy cannot exhaustively prove the assumption that a year later the Franciscans went to Özbeg and received a yarliq in 1314 in parallel with the visit of the Genoese representatives to the Khan. Nevertheless, it should be noted here that during negotiations with the Mongol rulers, Italian merchants sought to defend not only their pragmatic interests, but also spiritual requests. Along with obtaining permission to establish their own trading quarters, western merchants received permission to build Catholic churches, and, apparently, Latin missionaries took part in their negotiations with the Mongol rulers. In particular, the Ilkhan Abu Said's yarliq of the end of 1320 (preserved in the Italian translation), which provided the Venetians with freedom of movement throughout all the cities of his domain and determined the terms of their trading activities and corresponding taxation, contained a separate paragraph securing the right of the "Latin Friars" to establish churches in any cities and villages of the Ilkhanate ${ }^{20}$. This paragraph immediately followed the paragraph that allowed Western merchants to es-

${ }^{17}$ The name of the cathedral church is mentioned in the above bull Ad universalis ecclesiae: "ut ecclesia sanctae Agnetis dicti loci Caphen. ex tunc haberetur et existeret perpetuis futuris temporibus cathedralis" [14, p. 143].

${ }^{18}$ See the forged yarliq's translation in [18, p. 112-118].

${ }^{19}$ See the Rus'ian translation of this yarliq in [6, p. 467-468].

20 "Item, se li nostri Frari Latini volesse far in alguna citade o logo del so imperio logo per soa oratio, che li lo possa far; e che alguna persona no li possa dir alguna cosa” [26, p. 99. See also 42 , p. 94]. 
tablish their own caravanserais in the same cities. Obviously, this paragraph met the requirement of the Government of the Venetian Republic, put forward in parallel with the request for the Ilkhan's protection of the merchants during their stay in his possessions. At the same time, this paragraph testified to Ilkhan's consent to comply with this requirement.

This requirement, approved by the Ilkhan Abu Said, reflected the desire of the Venetians to attend their churches in the territories of the Mongol rulers and to participate in masses held by Catholic priests in these churches; and the ubiquitous construction of Catholic churches in all the cities of the Mongol Empire, which were visited by Western merchants, was made possible thanks to the financial support and intercession provided by European merchants to the friars of the Franciscan and Dominican Orders, as the German Carmelite Johann of Hildesheim eloquently emphasized in his treatise On the Deeds and Acts of the Three Holy Kings ("De gestis et factis trium reum beatorum", written between 1364 and 1375): "For merchants from Lombardy and other rich lands, staying in those parts and often arriving there, take with them these Orders to those places and establish cloisters for them with the support of other merchants and faithful, generously supplying them with everything they need according to which of these Orders each of them prefers" 21 .

So, in 1299, the head of the Dominicans in the East, Franco of Perugia, founded a convent of the Friars Preachers in Caffa ${ }^{22}$ thanks to the financial support of local Genoese merchants, according to his obituary from the Chronicle of the Friars of St Dominic of Perugia (Cronica fratrum Sancti Dominici de Perusio) of an anonymous Dominican: "By the will of God, he arrived in Caffa, in the city that belongs to the Empire of the Tartars, and got there a place given to him by the Genoese. He also built a beautiful church there, to the great reverence of all Christian people",23. In turn, 19 years earlier (27 August 1280), Marco Polo Senior (senior uncle of the famous Marco Polo Junior) bequeathed the house that he owned in Soldaia to the local Franciscans, retaining the right of residence in this house for his son, Niccolo, and daughter, Marota: "Also, I bequeath my house, which I have in Soldaia, to the Minor Friars of the same city, keeping the right of residence for the above mentioned son of mine and my daughter, Marota, while they are alive" ${ }^{, 24}$.

Also, the letter of the Dominican General Master, Bérenger de Landore, addressed to Franco of Perugia on 20 October 1312, reflected the apparent dependence of the Caffa's Dominicans on Western merchants, although it also showed increased concern of the head of the Friars Preachers regarding the participation of the Dominicans in the east in their trading operations: "For indeed, I recently

21 "Nam mercatores de lombardia et alijs terris ditissimi qui in illis partibus degunt et frequenter perueniunt trahunt hos ordines ad illas partes et eis cum auxilio aliorum mercatorum et fidelium claustra fundant et omnia necessaria largiter eis ministrant secundum quod quiuis aliquis ordinem diligit" [the fifteenth century Codex at the Ambrosian Library in Milan, C 70 inf., fol. $475^{\mathrm{v}}$ ].

${ }^{22}$ Friar Franco went to Crimea after receiving the Boniface VIII's bull Immaculata lex Domini of 10 April 1299 and the corresponding powers of the Papal legate [13, p. 209].

23 "Disponente autem Deo, venit in Chaffam terram que ad imperium pertinet Tartarorum, ibidem locum recipiens a Ianuensibus sibi datum. Ecclesiam quoque edificavit pulcram cum magna devotione totius populi" [23, p. 67].

24 "Jtem domum meam quam habeo jn soldathya dimitto fratribus minoribus eiusdem loci, salua habitatione suprascriptorum filij \& filie mee marothe quamdiu uixerint" [25, p. 524]. 
learned from the message of some, not without great heartache, that some of the mentioned Pilgrim Friars, who voluntarily chose extreme poverty together with the poor and mendicant Christ, are more zealous in accumulating money than in eradicating vices. The most harmful thing is that they keep the mentioned money, undeserved alms, in the hands of merchants, so that the owner of this money does not remain unknown, and manage the money without the permission of the prelates, in contradiction with the statutes of the Order" 25 . Also, the Latin Bishop of Samarkand, Dominican Tommaso Mancasole da Piacenza, did not escape the temptation of enrichment and, finding himself in Tana, on the way to his diocesan chair (in the summer of 1330), he invested 50 liras in a commenda, that is, a trade agreement concluded with a merchant from Piacenza named Roberto di Ripalta, according to one notarial act from the archive of the hospital of Piacenza ${ }^{26}$. This document is an interesting testament to the flagrant violation of the Dominican Order's prescriptions by its prelate, but at the same time this act once again points out the cooperation between Latin missionaries and Western merchants.

\section{Terms of the Agreement of the Genoese with Özbeg Khan}

All these observations serve the purpose of demonstrating the validity of the assumption that the Franciscans of Caffa received the 1314 yarliq from Özbeg in parallel with the negotiations of representatives of Genoa with the Golden Horde Khan. However, unlike the Franciscans, who received full exemption from taxes from Özbeg, the subject of negotiations between the Genoese and the Khan was to be the amount of comercium or the main tax on the activities of Western merchants in the Golden Horde. The Özbeg's yarliq granted to the Venetians of Tana on 17 September 1332, determined this tax in the amount of three percent of the value of goods sold or consumed [11, p. 243]. This tax should have been levied in the same amount on Western merchants in Caffa, as Francesco Balducci Pegolotti claimed in that part of his Trading Guide (La Pratica della Mercatura), which contained information on the conditions of trade in the Golden Horde in the first half of the 1320s ${ }^{27}$ : "Tax on goods paid in Caffa. All categories of people, with the exception of the Genoese, pay three percent for export and import. The Genoese pay three and a half percent: half a percent goes to the community of the Genoese themselves, and three percent there goes to the Lord of Caffa" 28 .

25 "Nuper namque aliquorum relatu non sine magna cordis amaritudine intellexi, quod aliqui dictorum fratrum peregrinancium qui extremam paupertatem cum Christo paupere et mendico voluntarie elegerunt, plus student in congregandis pecuniis quam viciis extirpandis et quod censetur periculosius nec nota caret proprietarii, dictas pecunias indebite mendicatas tenent in manibus mercatorum et contra statuta ordinis ipsas dispensant absque licencia prelatorum" [28, p. 314].

${ }^{26}$ See the reference to this act in [42, p. 162, note 145].

${ }^{27}$ Pegolotti reported in the same part that a sommo (in this case, the monetary unit) in Tana was equal to 190 aspers [15, p. 25], and this fully corresponded to the information contained in one resolution of the Venetian Senate of 22 September 1322 [19, p. 17]. Sommo's value later changed. So, in the decree of the Venetian Senate of 23 March 1333, a sommo was equated with 160 aspers [Senato. Deliberazioni. Misti. 16: Registro [23/03/1333 - 21/02/1335], fol. $1^{\mathrm{r}}$ ].

28 "Diritto di mercatantia che si paga in Caffa. Tutte maniere di genti salvo i genovesi pagano 3 per centinaio traendo e entrando. Gienovesi pagano $31 / 2$ per centinaio; e 'l mezzo è della comunità de' genovesi medesimi, e li 3 per centinaio sono del signore di Caffa" [15, p. 26]. 
This statement by Pegolotti is the first clear reference to duties on European goods at Caffa in favor of the Khan's treasury; and, perhaps, the desire to impose this tax or increase it to three percent (or impose a double duty on both import and export of goods) was the real reason for the repressions that Toqta Khan could resort to after the Genoese probably refused to pay this tax. Apparently, under the new Khan, the Genoese, however, were forced to accept this requirement, which allowed them to settle again in Caffa legally, just as the Venetians of Tana managed to do later, recognizing as legitimate the increase of comercium to five percent in 1347 after they were expelled from Tana by Janibeg Khan four years earlier ${ }^{29}$.

The fact that Pegolotti meant by the "Lord of Caffa" its "Emperor," that is, the Golden Horde Khan, is confirmed in only one decree of the Office of Gazaria of 30 August 1316. This resolution specified that the Genoese consul of Caffa, that is, the official representative of the metropolis, had no right to recognize his vassal dependence on the Khan of the Golden Horde, as well as, curiously, on his wife. At the same time, the same resolution specified that in this case the "Emperor" of the Golden Horde was meant by the expression the "Lord of Caffa": "He (consul) is also obligated to swear that he will not become a vassal of the Emperor or Lord or Empress or Lady of Caffa all the time while he will serve as consul" ${ }^{, 30}$.

In the rest of their decisions, functionaries of the Office of Gazaria carefully avoided clarifying Caffa's status within the Golden Horde and mentioning the fact that in reality Caffa was subordinate primarily to Özbeg Khan and then to the comune of Genoa. This ambiguous silence of this fact became the object of criticism of the Venetians at the beginning of the reign of Janibeg in connection with the starting of an open conflict of both maritime republics with the new Khan. Due to this conflict, the governments of Genoa and Venice entered into a mutual agreement on the conditions of the embargo prohibiting all trade operations on the territory of the ulus of Jöchi (from 1 July 1344 to 1 July 1345). However, the commune of Caffa not only did not comply with the conditions of the embargo ${ }^{31}$, but also allowed itself to appropriate the right to collect the former Khan's comercium inside the city. This fact is evidenced by a protocol drawn up in October 1344 by the ambassadors of Venice, Marco Ruzzini and Giovanni Steno, sent to Janibeg and presenting a note of protest to the Genoese during their long stay in Caffa: "And if you, gentlemen inspectors and ambassadors of the comune of Genoa, would like to say that one can trade in Caffa, in the desire to say that Caffa itself belongs to the comune of Genoa, and not to the Emperor Janibeg, we, inspectors and ambassadors of the comune of Venice, say that you cannot say this justifiably, since the comune of Genoa has the city of Caffa from the Emperor on certain conditions and under certain agreements, and that the Lord Emperor himself keeps in Caffa his rectors and officials who administer justice and resolve issues relating to all people, except for the Genoese. And these officials also on behalf of this Emperor charge the comercium amounting to three percent in the mentioned Caffa both from the Genoese and from any other persons, as they actually do in Tana. So

${ }^{29}$ Cfr. the first yarliq of Janibeg Khan dated 30 September 1342, determining the amount of comercium at three percent, and his second yarliq of 26 December 1347, which increased it to five percent [11, p. 262, 312].

30 "Teneatur eciam iuramento quod non efficietur uassallus imperatoris uel domini uel imperatricis uel domine de Caffa quamdiu in ipso consulatus officio fuerit” [43, col. 401].

${ }^{31}$ These conditions were often violated by the Venetians themselves [21, p. 272]. 
[it should] say that the comune of Genoa in the mentioned city of Caffa has jurisdiction only over the Genoese, and not any other person. And if you, gentlemen inspectors and ambassadors of the comune of Genoa, would like to say that you charge comercium in Caffa, we, inspectors and ambassadors of the comune of Venice, say that the comercium that you charge applies only to your Genoese, and that it is legal for you to charge it as from yours citizens. But you should not charge a comercium from any other person and solve their issues, because if someone would like to [say] that Caffa itself is not in the Empire of Emperor Janibeg, they could not say it reasonably and truthfully" ${ }^{\prime 2}$.

\section{REFERENCES}

1. Assini A. Akty, sostavlennye v Prichernomor'e i Sredizemnomor'e notariyami Filippo Fasheto i Franchesko da Sil'va v 1314-1315 gg. = Atti rogati nel mar Nero e nel Mediterraneo dai notai Filippo Fasceto e Francesco da Silva nel 1314-1315 [Acts rogated in the Black Sea Region and the Mediterranean by Notaries Filippo Fascheto and Francesco da Silva in 1314-1315]. Prichernomor'e v srednie veka, No. 10: Notai genovesi in Oltremare: Atti redatti a Caffa ed in altre località del Mar Nero nei secoli XIV e XV=Akty genuezskikh notariev, sostavlennye $v$ Kaffe $i v$ drugikh gorodakh Prichernomor'ya $v$ XIV$X V v v$. [Black Sea Region in the Middle Ages, No. 10: Acts of the Genoese Notaries Rogated in Caffa and in Other Cities of the Black Sea Region in the fourteenth and fifteenth century]. Karpov S.P. (ed.). St. Petersburg: Aleteia, 2018, pp. 31-176. (In Russian, Italian, Latin)

2. Antonin, archimandrite (Kapustin). Zametki XII-XV veka, otnosyashchiesya $\mathrm{k}$ krymskomu gorodu Sugdee (Sudaku), pripisannye na grecheskom Sinaksare [Notes of the twelfth to fifteenth century related to the Crimean city of Sugdeia (Sudak) added to the Greek Synaxarion]. Zapiski Odesskogo obshchestva istorii i drevnostey [Notes of the Odessa Society of History and Antiquities]. Odessa: In the city printing house, 1863, vol. 5, pp. 595-628. (In Greek, Russian)

3. Balard M. La Romanie génoise (XII ${ }^{e}$ - début du XV siècle). Rome: École Française de Rome, 1978. 2 Vols. 1008 p. (with continuous pagination). (In French)

4. Brătianu G.I. Recherches sur le commerce génois dans la Mer Noir au XIII siècle. Paris: Librairie orientaliste Paul Geuthner, 1929. 359 p. (In French)

5. Bullarium Franciscanum Romanorum Pontificum constitutiones, epistolae, diplomata tribus Ordinibus Minorum, Clarissarum et Poenitentium a Seraphico Patriarcha

32 "Et si per vos dominos sindicos et ambaxatores comunis Ianuae vellet dicere quod mercaciones possent fieri in Caffa, vollendo dicere ipsum Caffam esse communis Ianue et non Imperatoris Çanibec, nos sindici et ambaxatores communis Veneciarum dicimus quod hic dicere de racione non potestis, cum commune Ianue habeat terram Caffe ab Imperatore cum certis condicionibus et pactis et quod ipse dominus Imperator teneat in Caffa suos rectores et officialles qui faciunt iustixiam et racionem in omnibus gentibus excepto quam in Ianuensibus, qui officialles etiam nomine ipsius domini Imperatoris exigunt in dicto Caffa nomine comercli tria per centenario tam a Ianuensibus quam a quibuscumque alliis personis, sicut proprie ipsi faciunt in Tana, ita quod commune Ianue in dicta terra Caffa dicere iurisdicionem habere inter suos Ianuenses tantum et non in aliqua allia persona. Et si per vos dominos sindicos et ambaxadores commune Ianue vellet dicere quod vos in Caffa excucitis comerclum, nos sindici et ambaxatores communis Veneciarum dicimus quod comerclum quod excucitis est tantum solomodo a vestris Ianuensibus, quibus licitum est a vobis ipsum ab ipsis excutere tamquam a vestris civibus, sed a nulla aliqua allia persona comerclum non excucitis nec de racione facere non debetis, ita quod si aliquis vellet ipse Caffa non esset in Inperiio Imperatoris Çanibec, hoc de racione et cum veritate dicere non posset" [see the protocol's text in 7, p. 204, note 251]. 
Sancto Francisco ab eorum originibus ad nostra usque tempora concessa, Vol. V: Benedicti XI, Clementis V, Ioannis XXII monumenta. Eubel C. (ed.). Romae: Typis Vaticanis, 1898. lii + 643 p. (In Latin)

6. Cherepnin V.L. (ed.). Pamyatniki russkogo prava, Iss. III: Pamyatniki prava perioda obrazovaniya russkogo tsentralizovannogo gosudarstva $X I V-X V$ vv. [Monuments of Russian Law, Vol. 3: Legal Monuments of the Period of the Formation of the Russian Centralized State in the fourteenth and fifteenth century]. Moscow: State publishing house of legal literature, 1955. 527 p. (In Russian)

7. Ciocîltan V. The Mongols and the Black Sea Trade in the Thirteenth and Fourteenth Centuries. Willcocks S. (tr.). Leiden; Boston: Brill, 2012. 321 p.

8. Desimoni C. Intorno alla impresa di Megollo Lercari in Trebisonda. Lettera di Bartolomeo Senarega a Giovanni Pontano pubblicata dal socio Cornelio Desimoni. Atti della Società Ligure di Storia Patria. Genova: Tipografia del Reale Istituto sordo-muti, 1879, vol. 13, fasc. 3, pp. 495-536. (In Italian, Latin)

9. DeWeese D.A. Islamization and Native Religion in the Golden Horde. Baba Tükles and Conversion to Islam in Historical and Epic Tradition. University Park: Pennsylvania State University Press, 1994. xvii +638 p.

10. Di Cosmo N. Mongols and merchants on the Black Sea Frontier in the thirteenth and fourteenth centuries: convergences and conflicts. Mongols, Turks, and Others. Eurasian Nomads and the Sedentary World. Amitai R., Biran M. (eds). Leiden; Boston: Brill, 2005, pp. 391-424.

11. Diplomatarium veneto-levantinum sive acta et diplomata res venetas, graecas atque levantis illustrantia a. 1300-1350. Thomas G.M., Tafel T.L.F. (eds). Venetiis: Typis Marci Visentini, 1880. xxvi 356 p. (In Latin, Italian)

12. Favereau M. Zolotaya Orda i Mamlyuki [The Golden Horde and Mamluks]. Zolotaya Orda v mirovoy istorii. Kollektivnaya monografiya [The Golden Horde in World History: A Collective Monograph]. Khakimov R.S. et al. (eds). Kazan: Marjani Institute of History of Tatarstan Academy of Sciences, 2016, pp. 334-353. (In Russian)

13. Fontes. Pontificia commissio ad redigendum codicem juris canonici orientalis, Series III, Vol. V, Tom. 2: Acta Romanorum pontificum ab Innocentio $V$ ad Benedictum XI (1276-1304). Delorme F.M., Tăutu A.L. (eds). Romae: Typis pontificae universitatis gregorianae, 1954. xvi 295 p. (In Latin)

14. Fontes. Pontificia commissio ad redigendum codicem juris canonici orientalis, Series III, Vol. VII, Tom. 2: Acta Ioannis XXII (1317-1334). Tăutu A.L. (ed.). Romae: Typis pontificae universitatis gregorianae, 1952. xix +302 p. (In Latin)

15. Francesco Balducci Pegolotti. La pratica della mercatura. Evans A. (ed.). Cambridge, Massachusetts: The Mediaeval Academy of America, 1936. liv + 443 p. (In Italian)

16. Gibb H.A.R. (tr.). The Travels of Ibn Battutta, A.D. 1325-1354. Cambridge: Published for the Hakluyt Society at the University Press, 1959, vol. II. xii +286 p.

17. Golubovich G. Biblioteca bio-bibliografica della Terra santa e dell'Oriente francescano, Tomo III: Dal 1300 al 1332. Quaracchi, Firenze: Collegio di S. Bonaventura, 1919. vi +496 p. (In Italian, Latin)

18. Grigor'ev V.V. O dostovernosti yarlykov, dannykh khanami Zolotoy Ordy russkomu dukhovenstvu. Istoriko-filologicheskoe issledovanie [On the Authenticity of the Yarliqs of the Golden Horde Khans Granted to the Rus'ian Clergy. Historical and Philological Research]. Moscow: The University Press, 1842. 132 p. (In Russian)

19. Karpov S.P. Drevneyshie postanovleniya Senata Venetsianskoy respubliki o navigatsii v Chernom more [The oldest decisions of the Senate of the Venetian Republic on navigation in the Black Sea]. Prichernomor'e v srednie veka [The Black Sea Region in the Middle Ages]. Moscow; St. Petersburg: Aleteia, 2000, no. 4, pp. 11-18. (In Russian)

20. Karpov S.P. Istoriya Trapezundskoy imperii [History of the Trebizond Empire]. St. Petersburg: Aleteia, 2007. 618 p. (In Russian) 
21. Karpov S. Venezia e Genova: rivalità e collaborazione a Trebisonda e Tana, secoli XIII-XV. Atti della Società Ligure di Storia Patria, Vol. XLI (CXV), Fasc. I: Genova, Venezia, il Levante nei secoli XII-XIV. Atti del Convegno Internazionale di Studi. GenovaVenezia, 10-14 marzo 2000. Genova: Nella sede della Società Ligure di Storia Patria, 2001, pp. 257-272. (In Italian)

22. Khwand-Amir. Istoriya mongolov. Ot drevneyshikh vremen do Tamerlana [History of the Mongols. From the Most Ancient Times to Tamerlane]. Grigor'ev V. (tr.). St. Petersburg: At Karl Krai's printing house, 1834. (In Russian)

23. Loenertz R.-J. Les missions dominicaines en Orient au XIV ${ }^{\mathrm{e}}$ siècle et la Société des Frères pérégrinants pour le Christ. Archivum Fratrum Praedicatorum. Romae: Institutum Historicum Fratrum Praedicatorum Romae ad S. Sabinae, 1932, vol. II, pp. 183. (In French)

24. Loenertz R.-J. La Société des Frères Pérégrinants. Étude sur l'Orient Dominicain. Roma: Istituto Storico Domenicano, 1937, vol. I. xii + 209 p. (In French)

25. Marco Polo. The Description of the World. Moule A.C., Pelliot P. (eds). London: George Routledge and Sons, 1938, vol. I. 595 p.

26. Mas-Latrie L. de. Privilège commercial accordé en 1320 à la République de Venise par un roi de Perse, faussement attribué à un roi de Tunis. Bibliothèque de l'École des chartes. Paris: Société de l'École des chartes, 1892, vol. 31, pp. 72-102. (In French, Italian)

27. Monleone G. Iacopo da Varagine e la sua Cronaca di Genova dalle origini al MCCXCVII, Vol. 1: Studio introduttivo. La vita e le opere di Iacopo da Varagine, $i$ manoscritti della Cronaca ecc. con un indice onomastico e quattro tavole fuori testo. Roma: Tipografia del Senato, 1941. xii +577 p. (In Italian, Latin)

28. Monumenta Ordinis Fratrum Praedicatorum historica, Tomus V: Litterae encyclicae magistrorum generalium Ordinis Praedicatorum ab anno 1233 usque ad annum 1376. Reichert B.M. (ed.). Romae: Ex typografia polyglotta S.C. de Propaganda Fidei, $1900.7+347$ p. (In Latin)

29. Moule A.C. Textus trium novorum documentorum e Tartaria Aquilonari an. 1314 1322. Archivum Franciscanum Historicum. Quaracchi, Firenze: Collegio S. Bonaventura, 1924, no. 17, pp. 65-71. (In Latin)

30. Myts V.L. Zavoevanie pozdnevizantiyskoy Tavriki mongolami: istorikoarkheologicheskiy kontekst katastrofy posledney chetverti XIII veka [The conquest of late Byzantine Taurica by the Mongols: historical and archaeological context of the disaster of the last quarter of the thirteenth century]. Stratum plus, No. 6: Pax Mongolica i evraziyskie potryaseniya XIII-XIV vv. [Pax Mongolica and Eurasian Shocks in the thirteenth and fourteenth centuries]. St. Petersburg; Chisinau; Odessa; Bucharest: University "Higher Anthropological School", 2016, pp. 69-106. (In Russian)

31. Nystazopoulo M.G. He en te Taurike Chersoneso polis Sougdaia apo tou XII mechri tou XV aîonos. Sumbole ê̂s ten historian tu mesaionikou Hellenismou tes Notiou Rosias. Athen: Hyperesia Archaiotētōn kai Anastēlōseōs, 1965. 188 p. (In Greek)

32. Ötemish Hajji. Kara tavarikh [Qara tavarikh]. Mirgaleev I.M., Sayfetdinova E.G., Khafizov S.T. (eds). Kazan: Marjani Institute of History of Tatarstan Academy of Sciences, 2017. (In Russian)

33. Pardessus J.M. Collection de Lois maritimes antérieures au XVIII ${ }^{e}$ siècle. Paris: Imprimerie royale, 1837, vol. IV. 609 p. (In French)

34. Pelliot P. Notes sur l'histoire de la Horde d'or: suivies de quelques noms turcs d'hommes et de peuples finissant en "ar". Paris: Librairie d'Amérique et d'Orient, Adrien Maisonneuve, 1949. 292 p. (In French)

35. Polnoe sobranie russkikh letopisey, Tom X: Letopisnyy sbornik, imenuemyy Patriarshey ili Nikonovskoy letopis'yu (prodolzhenie) [Complete Collection of Rus'ian Chronicles, Vol. 10: Chronicle Collection Called the Patriarchal or Nikon Chronicle (con- 
tinued)]. Bychkov A.F. (ed.). St. Petersburg: In the printing house of the Ministry of the Interior, 1885. $6+244$ p. (In Rusian)

36. Polnoe sobranie russkikh letopisey, Tom XVIII: Simeonovskaya letopis' [Complete Collection of Rus'ian Chronicles, Vol. 18: Simeonov's Chronicle]. Presnyakov A.E. (ed.). St. Petersburg: Printing house of M.A. Aleksandrov, 1913. iii + 316 p. (In Rusian)

37. Polnoe sobranie russkikh letopisey, Tom XXIII: Ermolinskaya letopis' [Complete Collection of Rus'ian Chronicles, Vol. 23: Ermolin's Chronicle]. Pokrovskiy F.I. (ed.). St. Petersburg: Printing house of M.A. Aleksandrov, 1910. 252 p. (In Rusian)

38. Polnoe sobranie russkikh letopisey, Tom XXIV: Tipografskaya letopis' [Complete Collection of Rus'ian Chronicles, Vol. 24: Typographical Chronicle]. Rozanov S.P., Shakhmatov A.A., Presnyakov A.E. (eds). Petrograd: Second State printing house, 1921. $\mathrm{xvi}+272$ p. (In Rus'ian)

39. Polnoe sobranie russkikh letopisey, Tom XXV: Moskovskiy letopisnyy svod kontsa $X V$ veka [Complete Collection of Rus'ian Chronicles, Vol. 25: Moscow Chronicle Collection of the end of the fifteenth century]. Tikhomirov M.N. (ed.). Moscow; Leningrad: Publishing house of the USSR Academy of Sciences, 1949. 464 p. (In Rusian)

40. Polnoe sobranie russkikh letopisey, Vol. XXX: Vladimirskiy letopisets. Novgorodskaya vtoraya (Arkhivskaya letopis') [Complete Collection of Rus'ian Chronicles, Vol. 30: Vladimir Chronicle. Novgorod Second (Archival) Chronicle]. Tikhomirov M.N. (ed.). Moscow: Nauka, 1965. 239 p. (In Rusian)

41. Promis V. (ed.). Continuazione della Cronaca di Jacopo da Varagine. Atti della Società Ligure di Storia Patria. Genova: Tipografia del Reale Istituto sordo-muti, 1876, vol. 10, fasc. IV, pp. 493-512. (In Italian, Latin)

42. Richard J. La Papauté et les missions d'Orient au Moyen Âge (XIII ${ }^{e}-X V^{e}$ siècles). Rome: École Française de Rome, 1977. xxxiv + 331 p. (In French)

43. Sauli L. (ed.). Imposicio Officii Gazariae. Monvmenta Historiae Patriae. Leges mvnicipales. Avgvstae Tavrinorvm: E regio typographeo, 1838, vol. I, cols. 297-430. (In Latin)

44. Spuler B. Die Goldene Horde: Die Mongolen in Rußland, 1223-1502. Wiesbaden: Otto Harrassowitz, 1965. xviii +638 p. (In German)

45. Tardy L. Madjar - The name of Eastern Hungarians in an Italian document from Caffa, 1310. Acta Antiqua Academiae Scientiarum Hungaricae = Acta Antiqua: A Journal of the Hungarian Academy of Sciences. Tomus XXX. Harmatta J. (ed.). Budapest: Akadémiai Kiadó, 1982-1984, pp. 451-456.

46. Tizengauzen V.G. Sbornik materialov, otnosyashchikhsya $k$ istorii Zolotoy Ordy, Tom 1: Izvlecheniya iz sochineniy arabskikh [Collected Materials Related to the Golden Horde History, Vol. 1: Excerpts from Arabic Writings]. St. Petersburg: Printing house of the Imperial Academy of Sciences, 1884. xvi +563 p. (In Arabic, Russian)

47. Tizengauzen V.G. Sbornik materialov, otnosyashchikhsya $k$ istorii Zolotoy Ordy, Tom 2: Izvlecheniya iz persidskikh sochineniy [Collected Materials Related to the Golden Horde History, Vol. 2: Excerpts from Persian Writings]. Romaskevich A.A., Volin S.L. (eds). Moscow; Leningrad: Publishing house of the USSR Academy of Sciences, 1941. 306 p. (In Russian, Persian)

48. Wyngaert A. van den (ed.). Sinica Franciscana, Vol. I: Itinera et relationes fratrum minorum saeculi XIII et XIV. Quaracchi, Firenze: Collegio di S. Bonaventura, 1929. cxvii + 637 p. (In Latin) 
About the author: Roman Hautala - Ph.D. (History), Senior Research Fellow, Usmanov Center for Research on the Golden Horde and Tatar Khanates, Marjani Institute of History of Tatarstan Academy of Sciences (7A, Baturin Str., Kazan 420111, Russian Federation); Docent, Department of History at the Faculty of Humanities, University of Oulu, (1, Pentti Kaiteran Str., Historia, PL 1000, 90570, University of Oulu, Oulu, Finland); ORCID: 0000-0003-3898-0107, ResearcherID: H-9114-2016. E-mail: romanhautala@gmail.com

\title{
ПОТЕРЯ И ПОВТОРНОЕ ОБРЕТЕНИЕ КАФФЫ: СТАТУС ГЕНУЭЗСКОЙ ФАКТОРИИ В ГРАНИЦАХ ЗОЛОТОЙ ОРДЫ
}

\author{
Роман Хаутала ${ }^{1,2}$ \\ ${ }^{1}$ Институт истории им. Ш. Марджани АН РТ \\ Казань, Российская Федерачия \\ ${ }^{2}$ Университет Оулу \\ Оулу, Финляндия \\ romanhautala@gmail.com
}

Цель исследования: проанализировать обстоятельства как вооруженного конфликта генуэзцев Каффы с войсками золотоордынского хана Токты в 1307-1308 годах, закончившегося временным изгнанием итальянских купцов с джучидской территории, так и их возвращения в Каффу при племяннике и преемнике Токты, хане Узбеке.

Материалы исследования: информация о конфликте между генуэзцами и ханом Токтой содержится в анонимном продолжении хроники генуэзского архиепископа и хрониста Якопо да Вараджине середины XIV века, в хрониках мамлюкских авторов Рукн ад-дин Бейбарса и ан-Нувайри и в местном греческом источнике, а именно, в Сугдейском синаксаре. В свою очередь источники, которые предоставляют информацию об обстоятельствах и условиях возвращения генуэзцев, намного более разнообразны. Разумеется, наиболее важная информация содержится в официальный документах Генуи и Каффы. Очень ценные подробности содержатся в миссионерских источниках францисканцев, проповедовавших евангелие внутри Золотой Орды. Со своей стороны, францисканские сведения полезно сравнить с информацией русских источников касательно сношений католических и православных прелатов с ханом Золотой Орды.

Новизна исследования: использование францисканских источников для дополнения анализа взаимоотношений генуэзской фактории с местной властью представляется чрезвычайно полезным.

Результаты исследования: анализ конфликта генуэзцев с местной властью и условий их возвращения, обговоренных с новым ханом Золотой Орды, выявляет тот очевидный факт, что Каффа, несомненно разросшаяся в золотоордынский период благодаря деятельности генуэзских переселенцев, должна была признавать свое подчинение джучидским правителям с самого своего появления, и генуэзская администрация признала эту зависимость во время восстановления Каффы в первые годы правления хана Узбека. 
Ключевые слова: история Золотой Орды, итальянская торговля в Монгольской империи, генуэзская фактория Каффы, католическая миссионерская деятельность на востоке, латинские и мусульманские источники

Для цитирования: Hautala R. The Loss and Reacquisition of Caffa: The Status of the Genoese Entrepôt within the Borders of the Golden Horde // Золотоордынское обозрение. 2021. Т. 9, № 2. С. 247-263. DOI: 10.22378/2313-6197.2021-9-2.247-263

Сведения об авторе: Роман Хаутала - Ph.D. (история), старший научный сотрудник Центра исследований Золотой Орды и татарских ханств им. М.А. Усманова Института истории им. Ш. Марджани АН РТ (420111, ул. Батурина, 7А, Казань, Российская Федерация); доцент кафедры истории гуманитарного факультета университета Оулу, (90570, ул. Пентти Кайтера, 1, История, почтовый ящик 1000, университет Оулу, Оулу, Финляндия); ORCID: 0000-0003-3898-0107, ResearcherID: H-9114-2016. E-mail: romanhautala@gmail.com 